\section{Vertical transmission of the human papillomavirus: a systematic quantitative review}

\author{
Transmissão vertical do papilomavírus humano: \\ uma revisão sistemática quantitativa
}

\footnotetext{
1 Programa de

Pós-graduação em Epidemiologia, Universidade Federal do Rio Grande do Sul, Porto Alegre, Brasil. 2 Divisão de Pesquisa, Instituto Dante Pazzanese de Cardiologia, São Paulo, Brasil.

3 Programa de Pós-graduação em Ciências Médicas, Universidade Federal do Rio Grande do Sul, Porto Alegre, Brasil.

4 Faculdade de Medicina,

Universidade Federal do Rio Grande do Sul, Porto Alegre, Brasil.

Correspondence L. R. Medeiros Programa de Pós-graduação em Epidemiologia Universidade Federal do Rio Grande do Sul. Rua José de Alencar 1244, apto. 1009, Porto Alegre, RS 90880-480, Brasil. lidia@portoweb.com.br
}

\section{Abstract}

In order to better understand the exact mode and risk of vertical transmission in asymptomatic pregnant women, as well as the relationship between HPV transmission and mode of delivery, we have proposed this systematic quantitative review of prospective cohort studies. A comprehensive search was performed in the Cochrane Library, MEDLINE, LILACS, CANCERLIT, and EMBASE, as well as in the reference lists from the identified studies. Nine primary studies, which included 2,111 pregnant women and 2,113 newborns, met our selection criteria and were analyzed. A positive HPV test in the mother increased the risk of vertical HPV transmission (RR: 4.8; 95\%CI: 2.2-10.4). We also observed a higher risk of HPV infection after vaginal delivery than after cesarean section (RR: 1.8; 95\%CI: 1.3-2.4). The results of this meta-analysis showed the HPV DNA-positive rate only after birth, but an HPV DNA-positive neonatal sample does not necessarily indicate infection; it could merely indicate contamination (perinatal HPV contamination may have occurred). Infants born through vaginal delivery were at higher risk of exposure to $H P V$.

Systematic Review (Publication Type); MetaAnalysis; Vertical Transmission; Papillomavirus

\author{
Lidia Rosi Medeiros 1 \\ Anaelena Bragança de Moraes Ethur 1 \\ Juliana Balbinot Hilgert 1 \\ Roselaine Ruviaro Zanini 1 \\ Otávio Berwanger 1,2 \\ Mary Clarisse Bozzetti 3,4 \\ Luciane Calil Mylius 3
}

\section{Introduction}

Human papillomavirus (HPV) infection is highly common among sexually active young adults, with an estimated prevalence between $20.0 \%$ and $46.0 \% 1$. HPV oncogenic types are the principal cause of cervical cancer, because they are capable of inducing cellular immortalization with transformation to the malignant phenotype and loss of tumor suppressor genes 1,2 . In children, the virus can cause recurrent respiratory papillomatosis (RRP), a benign and rare disease almost always caused by one of two HPV types, HPV6 or HPV11. However, cervical cancer is an aggressive neoplasm that produces considerable morbidity 3,4 .

The association between sexual activity and cervical cancer has been known. It is also well recognized that high-risk HPV is spread by sexual activity 1 . There is growing evidence that HPV infection is acquired through non-sexual routes, and that one potential route is motherto-child transmission in the perinatal period $5,6,7,8$. Although epidemiological trials suggest the possibility of non-sexual transmission, there is evidence of vertical transmission, presumably occurring during passage of the fetus through an infected birth canal. The virus could also be transmitted by ascending infection, principally after premature rupture of membranes 5,6,7. Elective cesarean delivery could benefit infants of HPV DNA-positive mothers by reducing the 
neonatal contamination rate 8 . However, whether cesarean delivery could prevent transmission of the virus from HPV-positive mothers remains to be determined 8 .

In order to better understand the exact mode and risk of vertical transmission in asymptomatic pregnant women, as well as the relationship between HPV transmission and mode of delivery, we have proposed this systematic quantitative review.

\section{Methods}

\section{Search strategy}

We conducted a complete search of MEDLINE (OVID version) (1966 to April 2004), CINAHL (1982 to April 2004), LILACS (1980 to April 2004), EMBASE (Excepta Medica Database - 1980 to April 2004), Cochrane Central (1984 to April 2004). The following key words were used: HPV, pregnancy, newborn infants, vertical transmission, maternal-fetal transmission, perinatal infection, and perinatal transmission. Reference lists of all available primary studies were reviewed to identify additional relevant citations. There were no language restrictions. We attempted to contact the respective authors.

\section{Selection criteria}

This was a review of prospective cohort studies including pregnant women from all races and ages which examined transmission of HPV infection to newborns. HPV infection was investigated by polymerase chain reaction (PCR) in the maternal cervix between 20 and 40 weeks of gestation, and in the newborn infant's oral mucosa and/or genital area at delivery. Retrospective cohort studies, case-control studies, and case-series were excluded.

Three outcomes were measured: (1) HPV prevalence in pregnant women and newborns in each trial; (2) risk of mother-to-child HPV transmission defined as a positive HPV test (PCR); (3) risk of mother-to-child HPV transmission according to mode of delivery.

The reviewed studies were identified independently by four investigators (L. R. M., A. B. M. E., R. R. Z. and O. B. S.). All trials which appeared relevant on the basis of "title", "abstract", and "MeSH headings" were selected for full review by three independent reviewers. Articles were only rejected on initial screening if it could be determined from the title or abstract that the article was not a report of a prospective cohort study. Final inclusion and exclusion was made with reference to a checklist, which consisted of items based on the selection criteria.

\section{Quality assessment}

All articles meeting the eligibility criteria were assessed for their methodological quality. This assessment involved scrutinizing study designs and relevant features of population, test, and reference standards 9,10. Each trial's quality was assessed by two different methods. In the first method the results were summarized using the Ottawa-Newcastle system 10, in particular the use of stars awarded for each criterion in three domains (cohort selection, cohort comparability, and outcome) (Table 1). Studies were further assessed for methodological quality with reference to the Oxford Center for EvidenceBased Medicine Levels of Evidence Classification rubric 11. Only studies with Oxford Evidence Levels 1 to 3 were considered classified as high-quality, while those with levels 4 and 5 were excluded. These features included the data collection and patient selection methods, definition of a positive HPV test (PCR) in pregnant women and newborns, and presence of verification bias 12,13,14,15.

\section{Data extraction}

English-language articles were assessed by 2 reviewers (L. R. M. and A. B. M. E.) and those published in other languages were evaluated independently by 2 different reviewers (R. R. Z. and O. B. S.) following translation (when necessary). Disagreements were resolved by consensus, and when this was not possible, by arbitration with a fifth reviewer (M. C. B.).

From the potentially relevant articles, four reviewers independently selected the studies (based on the full-text format) for inclusion in this review. Thus, three outcomes were considered: (1) HPV prevalence in pregnant women and newborns; (2) risk of mother-to-child HPV transmission; (3) risk of mother-to-child HPV transmission according to mode of delivery. HPV prevalence data were calculated separately for sources with positive and negative results. Transmission risk data were abstracted as 2x2 tables (newborns HPV-positive/negative versus mothers HPV-positive/negative). Similarly, a contingency table was produced for 
Ottawa-Newcastle quality assessment scale cohort studies 10.

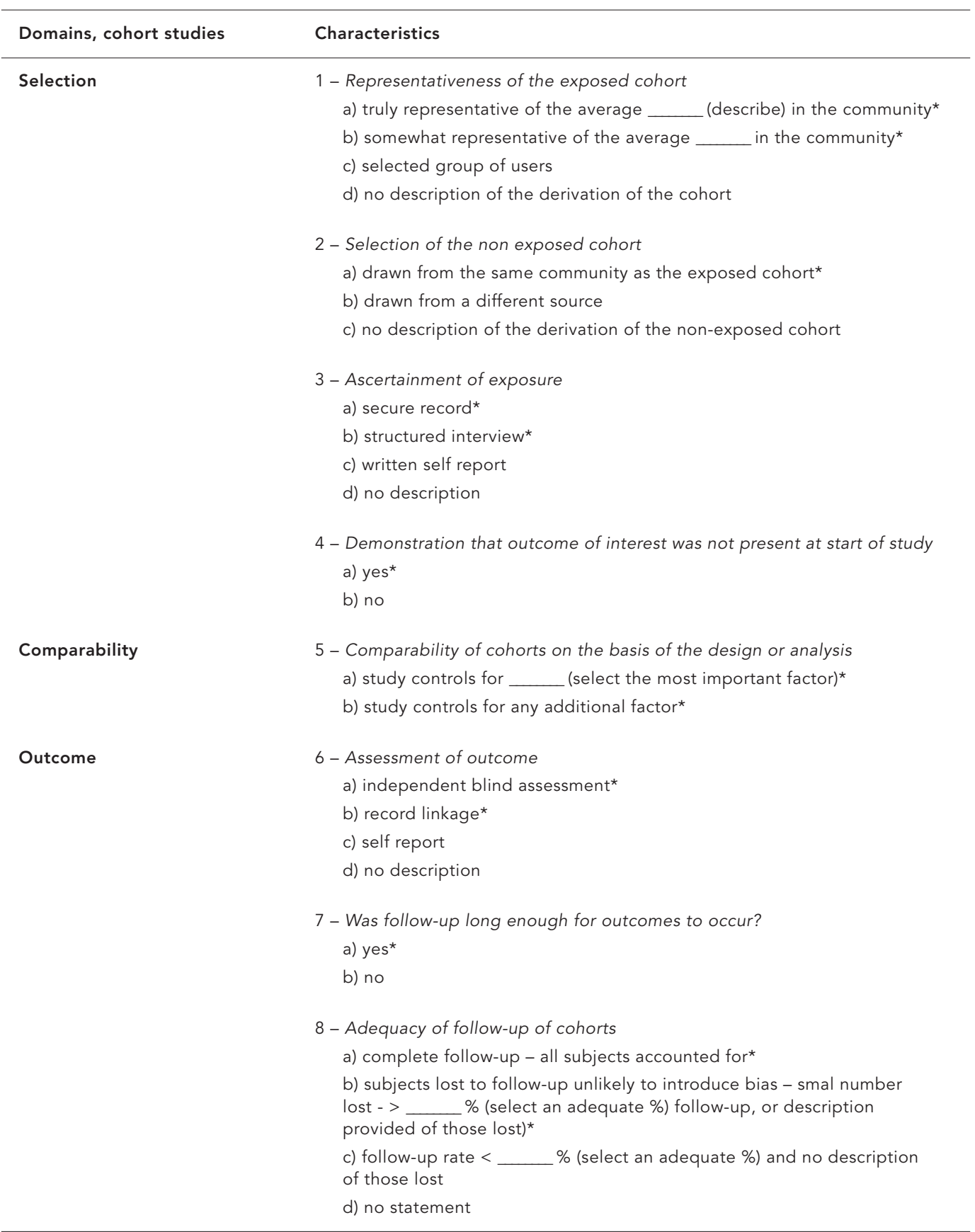

* A study can be awarded a maximum of one star for each numbered item within the selection and outcome categories. A maximum of two stars can be given for comparability. 
mother-to-child HPV transmission risk according to mode of delivery (newborns HPV-positive/cesarean versus newborns HPV-positive/ vaginal delivery).

\section{Statistical aspects}

To evaluate agreement between study eligibility and methodological quality assessment, the observed percentage agreement and $\kappa$ coefficient for inter-rater reliability were calculated 12. HPV prevalence rates in pregnant women and newborns were calculated by pooled estimates in each trial. For two other outcomes, in each trial we constructed $2 \times 2$ contingency tables. Relative risk (RR) and the respective $95 \%$ confidence intervals $(95 \% \mathrm{CI})$ were calculated for all effect size estimates for both individual studies and pooled estimates. Summary risk estimates were calculated using a general-variance-based fixed effect model (assessed with a homogeneity test), and the relative risks were pooled with a random effects model in cases of heterogeneity 14,15 . We tested for homogeneity of the combined effect sizes by the $\chi^{2}$ test, with $\mathrm{p}<0.05$ indicating significant heterogeneity 14,15 . When the $2 \times 2$ tables contained 0 cells, 0.5 was added to each cell to enable our calculations to be made. Data analyses were done using the Comprehensive Meta-Analysis and Review Manager software (RevMan).

\section{Sensitivity analysis}

To evaluate the stability of the overall risk estimate, a sensitivity analysis was performed by iteratively eliminating each study and calculating the resulting RR 15. The robustness of the results was tested by repeating the analysis using different statistical models (fixed and random effects model) 15 . We did not use funnel plots because there are numerous and confounding factors that may introduce heterogeneity in the context of observational meta-analysis 15 .

\section{Results}

\section{Study identification and eligibility}

Figure 1 summarizes the study selection process. Our initial search identified 486 articles. Twenty-five met the initial eligibility criteria, and full-text articles were retrieved. We excluded 16 studies 6,7,16,17,18,19,20,21,22,23,24,25,26,27,28,29, leaving 9 included in the analysis 30,31,32,33,34,35,36, 37,38 , involving a total of 2,111 pregnant women and 2,113 newborns. Inter-rater agreement for
Figure 1

Study selection process.

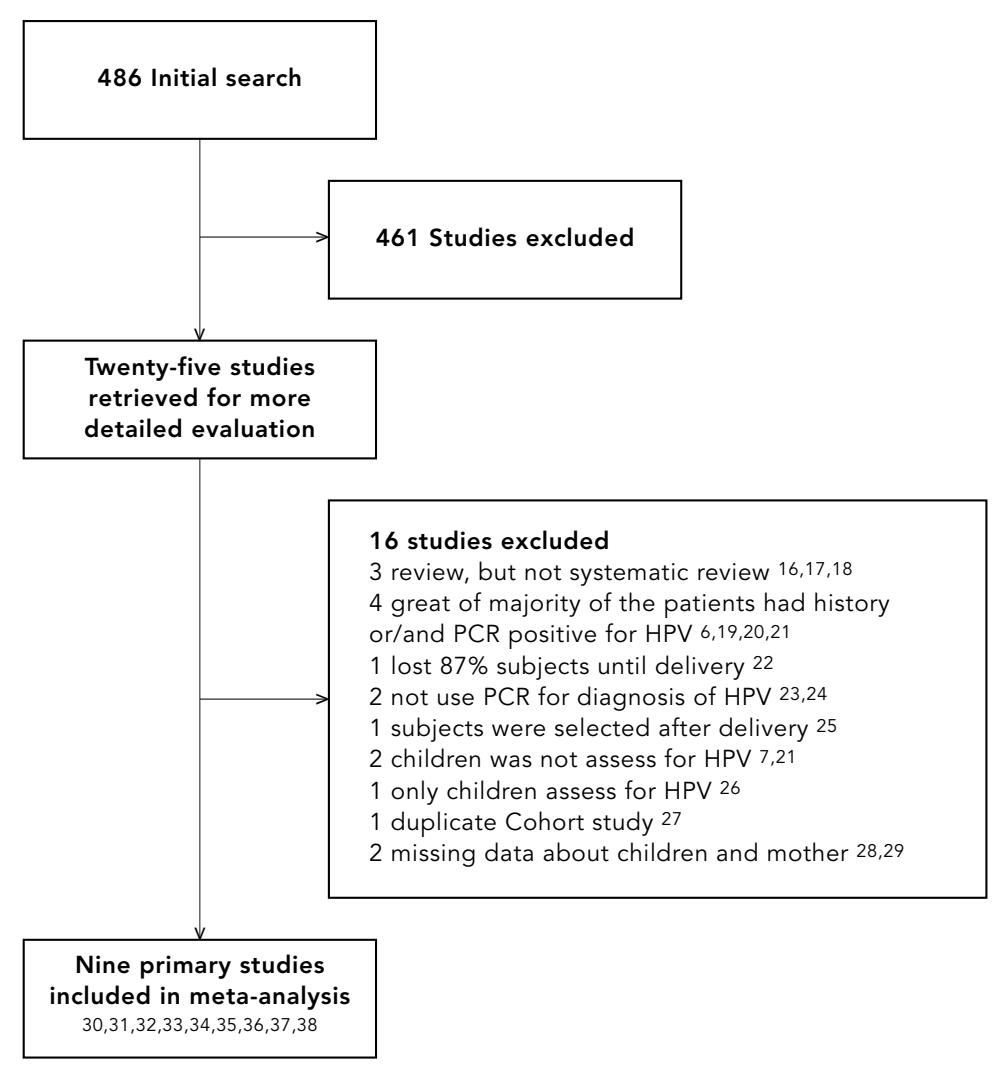

cluded in meta-analysis $30,31,32,33,34,35,36,37,38$

study eligibility was $79.0 \%(\kappa=0.64)$, indicating good agreement 12 .

\section{Study description}

Table 2 summarizes the details of participants, outcomes, and quality assessment of the studies selected for meta-analysis. Participants' ages across studies ranged from 16 to 45 . All nine were prospective cohorts from a narrow population, but included sufficient details and diagnostic reference standards 30,31,32,33,34,35,36, 37,38 . There were six studies with high methodological quality, satisfying greater than $86.0 \%$ of the criteria for study quality (seven or more stars for each quality criterion in the OttawaNewcastle system) 30,31,32,33,34,36. However, two trials were classified as level 3B, because details of the patient population including age were not reported 37 , and the sample size was small $(\mathrm{n}=30) 38$. 
Table 2

Characteristics and assessment of quality of studies

\begin{tabular}{|c|c|c|c|c|c|c|c|c|c|c|c|c|c|c|c|c|c|c|}
\hline \multirow[t]{3}{*}{ Study } & \multirow[t]{3}{*}{ Year } & \multirow[t]{3}{*}{$\begin{array}{c}\text { Age } \\
\text { (range) }\end{array}$} & \multirow{2}{*}{\multicolumn{2}{|c|}{ Subjects }} & \multirow{2}{*}{\multicolumn{2}{|c|}{$\begin{array}{c}\text { Mother } \\
\text { HPV+ }\end{array}$}} & \multirow{2}{*}{\multicolumn{2}{|c|}{$\begin{array}{l}\text { Newborn } \\
\text { HPV- }\end{array}$}} & \multirow[t]{3}{*}{ Follow-up } & \multicolumn{8}{|c|}{$\begin{array}{c}\text { Newcastle-Ottawa } \\
\text { assessment } 10\end{array}$} & \multirow{3}{*}{$\begin{array}{l}\text { Oxford } \\
\text { evidence } \\
\text { level } 11\end{array}$} \\
\hline & & & & & & & & & & \multirow[b]{2}{*}{1} & Sele & tion & \multicolumn{3}{|c|}{$\begin{array}{l}\text { Compa- } \\
\text { rability }\end{array}$} & \multicolumn{2}{|c|}{ Outcome } & \\
\hline & & & Mother & Infant & $n$ & $\%$ & $\mathrm{n}$ & $\%$ & & & 2 & 3 & 4 & 5 & 6 & 7 & 8 & \\
\hline $\begin{array}{l}\text { Bandyopahyay } \\
\text { et al. } 30\end{array}$ & 2003 & $20-39$ & 135 & 135 & 38 & 36.8 & 14 & 10.0 & 12 months & * & * & * & * & * & * & * & - & $2 B$ \\
\hline $\begin{array}{l}\text { Pakarian } \\
\text { et al. } 31\end{array}$ & 1994 & $17-37$ & 31 & $32^{* *}$ & 20 & 65.0 & 12 & 39.0 & 6 weeks & * & * & * & * & * & * & * & * & $2 \mathrm{~B}$ \\
\hline $\begin{array}{l}\text { Puranen } \\
\text { et al. } 32\end{array}$ & 1997 & $18-40$ & 105 & $106^{\star *}$ & 42 & 39.0 & 39 & 37.0 & Delivery & * & * & * & * & * & * & * & * & $1 \mathrm{~B}$ \\
\hline Smith et al. 33 & 2004 & $18-45$ & 574 & 574 & 172 & 30.0 & 9 & 1.6 & 6 months & * & * & * & * & * & * & * & - & $1 \mathrm{~B}$ \\
\hline Tenti et al. 34 & 1999 & $16-43$ & 711 & 711 & 37 & 5.5 & 11 & 1.5 & 18 months & * & * & * & * & 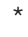 & * & * & * & $1 \mathrm{~B}$ \\
\hline Tseng et al. 35 & 1998 & $17-45$ & 301 & 301 & 68 & 22.5 & 27 & 9.0 & Delivery & * & * & * & * & A & * & - & - & $2 B$ \\
\hline Watts et al. 36 & 1998 & $16>30$ & 151 & 151 & 95 & 63.0 & 8 & 5.2 & 36 months & - & * & * & * & . & * & * & * & $2 B$ \\
\hline $\begin{array}{l}\text { Xiaoping } \\
\text { et al. } 37\end{array}$ & 1998 & $\begin{array}{l}\text { Not } \\
\text { reported }\end{array}$ & 73 & 73 & 26 & 35.6 & 5 & 19.0 & Delivery & - & * & * & * & * & * & - & - & $3 B$ \\
\hline Xu et al. 38 & 1995 & $22-36$ & 30 & 30 & 16 & 53.3 & 14 & 46.6 & Delivery & - & * & * & * & 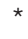 & * & - & - & $3 B$ \\
\hline Total & & & 2,111 & 2,113 & $\begin{array}{r}514 / \\
2,111\end{array}$ & 24.3 & $\begin{array}{r}139 / \\
2,113\end{array}$ & 6.5 & & & & & & & & & & \\
\hline
\end{tabular}

* The use of stars awarded for each criterion was based on the Ottawa-Newcastle system 10;

** One set of twins.

\section{HPV prevalence in pregnant women}

In vertical transmission studies, which included mothers who were positive and negative for HPV by PCR, the percentage of positive mothers varied from $5.5 \%$ to $65.0 \%$, with a pooled estimate of $24.3 \%$ (95\%CI: 22.0-26.0) (Table 2). Our meta-analysis showed 139 PCR HPV-positive newborns, with a transmission rate varying from $1.5 \% 21$ to $46.6 \% 25$ and a combined rate of $6.5 \%$ (95\%CI: $5.0-8.0$ ).

\section{Mother-to-child HPV transmission risk}

The combined relative risk for mother-to-child HPV transmission was 7.3 (95\%CI: 2.4-22.2; test for heterogeneity $\chi^{2}=46.3$, df $=8, \mathrm{p}<0.001$ ) $30,31,32,33,34,35,36,37,38$. Due to substantial heterogeneity, studies were also pooled with a random effects model, and sensitivity analysis was processed. Two studies with observed frequency equal zero in $2 \times 2$ tables 34,37 , three studies with more than $40.0 \%$ of HPV-positive mothers $31,36,38$, and one that failed to satisfy the study quality criteria ( $\geq 87.0 \%$ ) of the Ottawa-Newcastle system 35 were excluded. Thus, after sensitivity analysis, the pooled relative risk from three studies 30,32,33 was 4.8 (95\%CI: 2.1-10.9). There was homogeneity between these studies $\left(\chi^{2}=3.4, \mathrm{df}=2, \mathrm{p}=0.18\right)$ (Table 3; Figure 2).

\section{HPV transmission risk and mode of delivery}

Seven studies compared vaginal delivery and cesarean section in HPV-positive women 30,32, $33,34,35,37,38$. The combined relative risk for transmission according to mode of delivery was 1.8 (95\%CI: 1.3-2.4). There was statistical homogeneity between studies ( $\chi^{2}=4.20, \mathrm{df}=6, \mathrm{p}=0.6$ ), and both the fixed and random effect models produced the same values (Table 4; Figure 3).

\section{Discussion}

This was the first systematic review to evaluate vertical HPV transmission. The results of this review showed that there is a risk of mother-tochild HPV transmission when the mother presents a positive HPV test. Pooled mother-tochild HPV transmission was $6.5 \%$ and was higher after vaginal delivery than cesarean section $(18.0 \%$ versus $8.0 \%$ ). The combined relative risk of mother-to-child HPV transmission from nine studies was 7.3 (95\%CI: 2.4-22.2), but there was great heterogeneity between these studies 30,31,32,33,34,35,36,37,38. Therefore, in this and nearly all other meta-analyses, there was extensive clinical heterogeneity, because all studies were observational. This shows that simply combining the results of studies into one overall estimate can be misleading, and that 
Table 3

Infection of HPV in mother and newborn infants and risk of transmission.

\begin{tabular}{|c|c|c|c|c|c|c|c|c|c|}
\hline \multirow{3}{*}{$\begin{array}{l}\text { Study } \\
\text { Bandyopadhyay } \\
\text { et al. } 30\end{array}$} & \multirow{3}{*}{$\begin{array}{l}\text { Year } \\
2003\end{array}$} & \multirow{3}{*}{$\begin{array}{l}\text { Type of HPV (PCR) } \\
6,11,16,18,31,33 \\
113,109,334,456,514\end{array}$} & \multicolumn{2}{|c|}{$\begin{array}{c}\text { Mother HPV } \\
\text { positive/negative }\end{array}$} & \multirow{2}{*}{$\begin{array}{c}\begin{array}{c}\text { Newborn } \\
\text { HPV+ }\end{array} \\
7\end{array}$} & \multirow{2}{*}{$\begin{array}{c}\begin{array}{c}\text { Newborn } \\
\text { HPV- }\end{array} \\
31\end{array}$} & \multirow{2}{*}{$\begin{array}{c}\begin{array}{c}\text { Relative } \\
\text { risk }\end{array} \\
2.5\end{array}$} & \multirow{2}{*}{$\begin{array}{c}\begin{array}{c}95 \% \mathrm{Cl} \\
\text { (random } \\
\text { model) }\end{array} \\
0.9-6.7\end{array}$} & \multirow{2}{*}{$\begin{array}{l}p \\
0.1\end{array}$} \\
\hline & & & Positive & 38 & & & & & \\
\hline & & & Negative & 97 & 7 & 89 & & & \\
\hline \multirow[t]{2}{*}{ Pakarian et al. 31} & 1994 & $16,18,31,33$ & Positive & 20 & 10 & 10 & 1.8 & $0.6-5.2$ & 0.3 \\
\hline & & & Negative & 11 & 3 & 8 & & & \\
\hline \multirow[t]{2}{*}{ Puranen et al. 32} & 1997 & $6,11,16,18$ & Positive & 42 & 33 & 9 & 8.2 & $3.7-17.0$ & $<0.001$ \\
\hline & & & Negative & 63 & 6 & 57 & & & \\
\hline \multirow[t]{2}{*}{ Smith et al. 33} & 2004 & $2,6,7,11,16,18,30$ & Positive & 172 & 6 & 166 & 4.6 & $1.2-18.4$ & 0.01 \\
\hline & & $31,33,53,66$ & Negative & 402 & 3 & 399 & & & \\
\hline \multirow[t]{2}{*}{ Tenti et al. 34} & 1999 & $16,18,31,33,35,39,51,54$ & Positive & 37 & 11 & 26 & 40.8 & $24.5-6803.0$ & $<0.001$ \\
\hline & & $\begin{array}{r}58,59,68,70,6,11,13,38 \\
44,53,56,61,66,69,83,84\end{array}$ & Negative & 674 & 0 & 674 & & & \\
\hline \multirow[t]{2}{*}{ Tseng et al. 35} & 1998 & 16,18 & Positive & 68 & 37 & 31 & 42.2 & $13.0-132.0$ & $<0.001$ \\
\hline & & & Negative & 233 & 3 & 230 & & & \\
\hline \multirow[t]{2}{*}{ Watts et al. 36} & 1998 & 16,18 & Positive & 95 & 3 & 92 & 0.3 & $0.08-1.4$ & 0.2 \\
\hline & & & Negative & 56 & 5 & 51 & & & \\
\hline Xiaoping & 1998 & $6,11,42,43,44,31,33,35$ & Positive & 26 & 11 & 15 & 40.8 & $2.5-667.0$ & $<0.001$ \\
\hline et al. 37 & & $51,52,16,18,45,56$ & Negative & 47 & 0 & 47 & & & \\
\hline \multirow[t]{2}{*}{ Xu et al. 38} & 1995 & $16,18,35$ & Positive & 16 & 14 & 2 & 12.2 & $1.8-81.0$ & $<0.001$ \\
\hline & & & Negative & 14 & 1 & 13 & & & \\
\hline
\end{tabular}

Figure 2

Mother-to-child HPV transmission risk.

Review: Vertical transmission of HPV

Comparison: 01 vertical transmission of HPV

Outcome: 01 risk of tranmission of HPV from mother to newborn infant

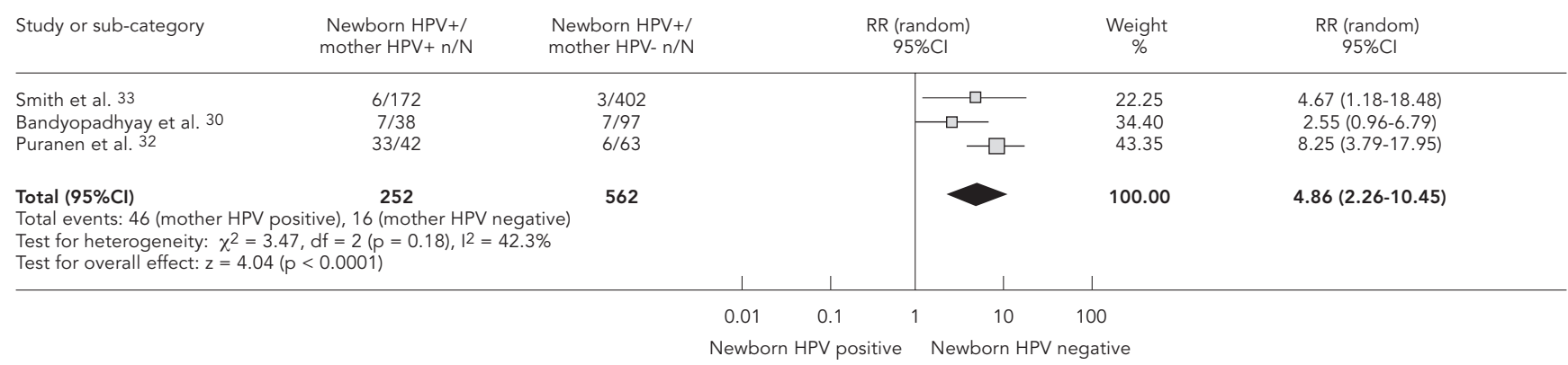


Table 4

Infants born to HPV-positive mothers according mode of delivery.

\begin{tabular}{|c|c|c|c|c|c|c|c|}
\hline Study & Year & Type of delivery & $\begin{array}{c}\text { Newborn } \\
\text { HPV+ }\end{array}$ & $\begin{array}{l}\text { Newborn } \\
\text { HPV- }\end{array}$ & $\mathrm{RR}$ & $\begin{array}{c}95 \% \mathrm{Cl} \\
\text { (random } \\
\text { model) }\end{array}$ & $p$ \\
\hline Bandyopahyay & 2003 & Vaginal & 2 & 9 & 0.9 & $0.2-4.3$ & 0.6 \\
\hline et al. 30 & & Cesarean & 5 & 22 & & & \\
\hline \multirow[t]{2}{*}{ Puranen et al. 32} & 1997 & Vaginal & 26 & 5 & 1.5 & $0.8-2.6$ & 0.04 \\
\hline & & Cesarean & 6 & 5 & & & \\
\hline \multirow[t]{2}{*}{ Smith et al. 33} & 2004 & Vaginal & 8 & 140 & 9.3 & $1.1-73.0$ & $<0.01$ \\
\hline & & Cesarean & 1 & 23 & & & \\
\hline \multirow[t]{2}{*}{ Tenti et al. 34} & 1999 & Vaginal & 11 & 18 & 6.9 & $0.4-105.0$ & 0.1 \\
\hline & & Cesarean & 0 & 8 & & & \\
\hline \multirow[t]{2}{*}{ Tseng et al. 35} & 1998 & Vaginal & 18 & 17 & 1.8 & $0.9-3.5$ & 0.07 \\
\hline & & Cesarean & 9 & 24 & & & \\
\hline \multirow[t]{2}{*}{ Xiaoping et al. 37} & 1998 & Vaginal & 7 & 7 & 1.5 & $0.5-3.9$ & 0.3 \\
\hline & & Cesarean & 4 & 8 & & & \\
\hline \multirow[t]{2}{*}{ Xu et al. 38} & 1995 & Vaginal & 2 & 0 & 1.6 & $0.8-3.4$ & 0.6 \\
\hline & & Cesarean & 7 & 7 & & & \\
\hline
\end{tabular}

Figure 3

Vertical HPV transmission risk according to mode of delivery.

Review: Vertical transmission of HPV

Comparison: 01 vertical transmission of HPV

Outcome: 02 risk of vertical transmission of HPV according to the mode delivery

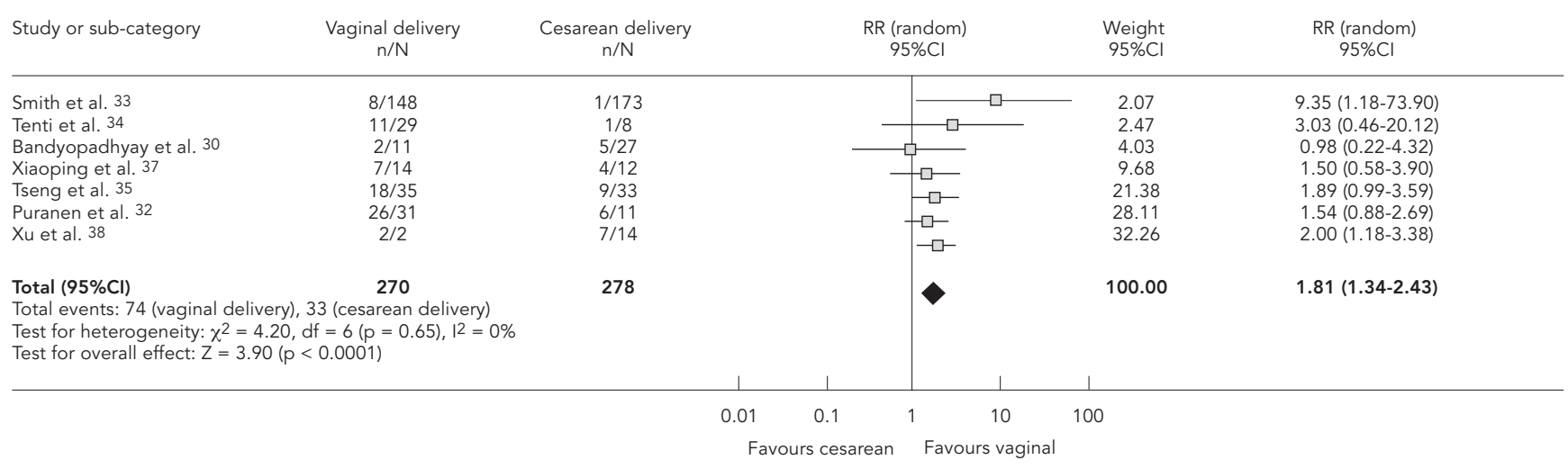


the reasons for heterogeneity need to be understood. The trials differed considerably in patient selection, number, and kind of HPV research, sample size, and duration of follow-up. After sensitivity analysis, the pooled relative risk was 4.8 , but with homogeneity between studies $30,32,33$.

Tenti et al. 34 and Xiaoping et al. 37 found a large effect size for risk of vertical HPV transmission, because they did not have HPV-positive newborns from HPV-negative mothers (0 cells in $2 \times 2$ tables). This probably occurred because one study had a small number of HPVpositive mothers $(5.2 \%) 34$, while the other had a limited sample $(n=73) 37$. Three other studies showed more than $40.0 \%$ of HPV-positive mothers 31,36,38. Meanwhile, Xu et al. 38 had a small sample size (30 patients). Some authors have attempted to detect HPV DNA in amniotic fluid 37,38, while two others detected HPV DNA in newborns from swab specimens collected from the oral and/or genital mucosa $30,31,32,33,34,35,36$.

Smith et al. 33 detected pair concordance of HPV types in only one mother/infant pair. Furthermore, one-third of newborns tested positive who were born to mothers who had tested HPV DNA-negative during pregnancy. In some studies there was the possibility of HPV DNA contamination, because they failed to use DNA sequencing, which reduces the probability of false-negative and false-positive results 34 . In addition, there are type-discordant cases between mothers and newborns, suggesting that many of these infants did not acquire the HPV from their mothers 33 .

The seven studies that evaluated the association between mode of delivery and vertical HPV transmission showed an increased risk of HPV transmission during vaginal delivery 30,32 , $33,34,35,37,38$. We found clinical homogeneity in several characteristics. All tested the same hypothesis. They measured similar endpoints and included only HPV-positive mothers with comparable characteristics (such as age and gestational age). According to some authors, cesarean delivery could reduce transmission because it avoids ingestion of infected maternal secre- tions or blood during fetal passage through the birth canal 8,35. However, Eppel et al. 7 suggest a possible trans-placental transmission route. We thus need to consider that true infection would have occurred in uterus rather than in the birth canal 39. We found an 8.0\% HPV- positive newborn rate following cesarean section. Therefore, the cesarean delivery would not be effective for protecting newborns from HPVpositive mothers.

This meta-analysis complied with the criteria for performing a rigorous systematic review planned a priori $13,14,15$. This included the use of study quality assessment 10,11 and investigation of homogeneity by fixed and random models to test the robustness of the results 13,14,15. On the other hand, the potential limitations of this systematic review were the limited number of studies, as well as data which were produced from observational trials. An overall effects measure could be biased, because the confounding factors introducing heterogeneity between studies. Another limitation is that we did not search for unpublished studies.

In this systematic review, the overall results suggest that perinatal HPV transmission occurred and that newborns are at higher risk of exposure to HPV with vaginal delivery as compared to cesarean section. However, because of the heterogeneity, the mathematically pooled results should be interpreted with caution. The results of this meta-analysis showed the HPV DNA-positive rate only after birth, but an HPV DNA-positive sample does not necessarily indicate infection; it could merely indicate contamination with infected maternal cells 13 . In this systematic review, only one study followed infants for an extended period of time (36 months) 37 .

In summary, there is insufficient evidence to recommend the generalization of cesarean section for all HPV DNA-positive mothers. The critical question is not how often infants are contaminated with HPV, but how often they are infected with HPV. More studies with better methodological quality, longer follow-up, and HPV testing by DNA sequencing in this area are needed. 
Para entendimento do modo exato de transmissão vertical e de seu risco em gestantes assintomáticas, bem como a relação entre a transmissão de HPV e o tipo de parto, foi proposta uma revisão sistemática quantitativa de coortes prospectivas. Foi realizada uma busca na Biblioteca Cochrane, MEDLINE, LILACS, CANCERLIT e EMBASE e nas referências dos estudos identificados. Nove estudos, que contaram com 2.111 gestantes e 2.113 recém-nascidos, foram incluídos de acordo com critério de seleção e foram analisados. O teste positivo para HPV na mãe aumentou o risco de transmissão vertical para $H P V$, com risco relativo $(R R=4,8$; IC95\%: 2,2-10,4). Foi observado um maior risco de infecção por HPV após parto vaginal ( $R R=1,8$; IC95\%: 1,3-2,4). Os resultados dessa metanálise mostraram uma taxa de positividade para o DNA do HPV somente após o nascimento, porém a taxa de positividade para DNA do HPV em amostras de recém-nascidos não indica infecção; pode indicar apenas contaminação. Concluiuse que a transmissão perinatal de HPV pode ocorrer e, após parto vaginal, os recém nascidos têm risco maior para exposição ao vírus.

Revisão Sistemática (Tipo de Publicação); Metanálise; Transmissão Vertical de Doença; Papilomavírus

\section{Contributors}

L. R. Medeiros, A. B. M. Ethur, R. R. Zanini, and M. C. Bozzetti contributed to all stages in the elaboration of the article. J. B. Hilgert and L. C. Mylius collaborated in the search strategies and methodological quality evaluation of the articles. O. Berwanger evaluated the methodological quality of the articles.

\section{Acknowledgments}

The authors thank Ms. Ruth Buist, who performed a comprehensive search in EMBASE.

\section{References}

1. Kirwan JMJ, Herrington CS. Human papillomavirus and cervical cancer: where are we now? Br J Obstet Gynaecol 2001; 108:1204-13.

2. van der Graaf Y, Nolijn A, Doornewaard H, Quint W, van Doorn LJ, van den Tweel J. Human papillomavirus and long-term risk of cervical neoplasia. Am J Epidemiol 2002; 156:158-64.

3. Kosko JR, Derkay CR. Role of cesarean section in prevention of recurrent respiratory papillomatosis - Is there one? Int J Pediatr Otorhinolaryngol 1996; 35:31-8.

4. Sun JD, Weatherly RA, Koopmann CF, Carey TE. Mucosal swabs detect HPV in laryngeal papillomatosis patients but not family members. Int J Pediatr Otorhinolaryngol 2000; 53:95-103.

5. Rice PS, Cason J, Best J, Banatvala JE. High risk genital papillomavirus infections are spread vertically. Rev Med Virol 1999; 9:15-21.

6. Cason J, Kaye JN, Jewers RJ, Kambo PK, Bible JM, Kell B, et al. Perinanal infection and persistence of human papillomavirus types 16 and 18 in infants. J Med Virol 1995; 47:209-18.

7. Eppel W, Word C, Frigo P, Ulm M, Kucera E, Czerwenka K. Human papillomavirus in the cervix and placenta. Obstet Gynecol 2000; 96:337-41.

8. Minkoff $\mathrm{H}$, Chervenak FA. Elective primary cesarean delivery. N Engl J Med 2003; 348:946-50.

9. Stroup DF, Berlin JA, Morton SC, Olkin I, Williamson GD, Rennie D, et al. Meta-analysis of observational studies in epidemiology: a proposal for reporting. JAMA 2000; 283:2008-12.

10. Wells GA, Shea B, O'Connell D, Peterson J, Welch V, Tugwell P. The Newcastle-Ottawa Scale (NOS) for assessing the quality of nonrandomized studies in meta-analyses. http://www.ohri.ca/programs/ clinical_epidemiology/oxford.htm (accessed on 19/Aug/2004).

11. Phillips B, Ball C, Sackett D, Badenoch D, Straus S, Haynes B, et al. Oxford centre for evidencebased medicine level of evidence grades of recommendations (May 2001). http://www.cebm.net/ background.asp (accessed on 23/Feb/2004).

12. Altman D. Practical statistics for medical research. 9th Edition, London: Chapman \& Hall; 1999.

13. Egger M, Smith GD, Schneider M. Systematic reviews of observational studies. In: Egger M, Smith GD, Altman DG, editors. Systematic reviews in health care: meta-analysis in context. 2nd Ed. London: BMJ Publishing Group; 2001. p. 211-27.

14. Sutton AJ, Abrams KR, Jones DR, Sheldon TA, Song F. Methods for meta-analysis in medical research. 1st Ed. Chichester: John Wiley \& Sons; 2000.

15. Egger M, Smith GD, Altman DG. Systematic reviews in health care: meta-analysis in context. $2^{\text {nd }}$ Ed. London: BMJ Publishing Group; 2001.

16. Cason J. Perinatal acquisition of cervical cancerassociated papillomaviruses. Br J Obstet Gynaecol 1996; 10:853-8.

17. Mant C, Cason J, Rice P, Best JM. Non-sexual transmission of cervical cancer-associated papillomaviruses: an update. Papillomavirus Report 2000; 11:1-5.

18. Rice PS, Cason J, Best JM, Banatvala JE. High risk genital papillomavirus infections are spread ver- 
tically. Rev Med Virol 1999; 9:15-21.

19. Kaye JN, Cason J, Pakarian FB, Jewers RJ, Kell B, Bible J, et al. Viral load as a determinant for transmission of human papillomavirus type 16 from mother to child. J Med Virol 1994; 44:415-21.

20. Kaye JN, Starkey WG, Kell B, Biswas C, Raju KS, Best JM, et al. Human papillomavirus type 16 in infants: use of DNA sequence analysis to determine the source of infection. J Gen Virol 1996; 77:1139-43.

21. Fife KH, Katz BP, Brizendine EJ, Brown DR. Cervical human papillomavirus deoxyribonucleic acid persists throughout pregnancy and decreases in the postpartum period. Am J Obstet Gynecol 1999; 180: 1110-4.

22. Alberico S, Pinzano R, Comar M, Toffoletti F, Maso G, Ricci G, et al. Trasmissione materno-fetale del papillomavirus umano. Minerva Gynecol 1996; 48:199-204.

23. Smith EM, Johnson SR, Cripe T, Periman S, McGuinness G, Jiang D, et al. Perinatal transmission and maternal risk of human papillomavirus infection. Cancer Detect Prev 1995; 19:196-205.

24. Sedlacek TV, Lindheim S, Eder C, Hasty L, Woodland M, Ludomirsky A, et al. Mechanism for human papillomavirus transmission at birth. Am J Obstet Gynecol 1989; 161:55-9.

25. Fredericks BD, Balkin A, DanielHW, Schonrock J, Ward B, Frazer IH. Transmission of human papillomaviruses from mother to child. Aust N Z J Obstet Gynaecol 1993; 33:30-2.

26. Rice PS, Mant C, Cason J, Bible JM, Muir P, Kell B, et al. High prevalence of human papillomavirus type 16 infection among children. J Med Virol 2000; 61:70-5.

27. Puranen M, Yliskoski M, Saarikoski S, Syrjanen K, Syrjanen S. Vertical transmission of human papillomavirus from infected mothers to their newborn babies and persistence of the virus in childhood. Obstet Gyneco 1996; 174:694-9.

28. Peng P, Weng X, Gu Z. Detection of the asymptomatic infection by human papillomavirus in pregnant women and neonates. Zhonghua Fu Chan Ke Za Zhi 2000; 35:523-6.
29. Mazzatenta C, Fimiani M, Rubegni P, Andreassi L, Buffi P, Messina C. Vertical transmission of human papillomavirus in cytologically normal women. Genitourin Med 1996; 72:446-7.

30. Bandyopadhyay S, Sen S, Majumdar L, Chatterjee R. Human papillomavirus infection among Indian mothers and their infants. Asian Pac J Cancer Prev 2003; 4:179-84.

31. Pakarian F, Kell B, Best JM. Cancer associated human papillomaviruses: perinatal transmission and persistence. Br J Obstet Gynaecol 1994; 101: 514-7.

32. Puranen M; Yliskoski MH; Saarikoski SV; Syrjänen KJ; Syrjänen SM. Exposure of an infant to cervical human papillomavirus infection of the mother is common. Am J Obstet Gynecol 1997; 176:1039-45.

33. Smith EM, Ritchie JM, Yankowitz J, Swarnavel S, Wang D, Haugen TH, et al. Human papillomavirus prevalence and types in newborns and parents. Sex Transm Dis 2004; 31:57-62.

34. Tenti P, Zappatore R, Migliora P, Spinillo A, Belloni C, Carnevali L. Perinatal transmission of human papillomavirus from gravidas with latent infection. Obstet Gynecol 1999; 93:475-8.

35. Tseng C, Liang C, Soong Y, Pao C. Perinatal transmission of human papillomavirus infants: relationship between infection rate and mode of delivery. Obstet Gynecol 1998; 91:92-6.

36. Watts DH, Koutsky LA, Holmes KK, Goldman D, Kuypers J, Kiviat NB, Galloway DA. Low risk of perinatal transmission of human papillomavirus: Results from a prospective cohort study. Am J Obstet Gynecol 1998; 178:365-73.

37. Xiaoping W, Qingyi Z, Huiling R. Maternal-fetal transmission of human papillomavirus. Chin Med J 1998; 11:726-7.

38. Xu S, Liu L, Lu S, Ren S. Clinical observation on vertical transmission of human papillomavirus. Chin Med Sci J 1998; 13:29-31.

39. Winer RL, Koutsky LA. Delivering reassurance to parents: perinatal human papillomavirus transmission is rare. Sex Trans Dis 2004; 31:63-4.

Submitted on $20 /$ Sep/2004

Approved on 15/Dec/2004 